DOI https://doi.org/10.36059/978-966-397-162-9/88-115

\title{
THE STRUCTURAL ANALYSIS \\ OF THE INVESTMENT MECHANISMS OFTHE PUBLIC POLICYINTHE SOCIAL DEVELOPMENT
}

\section{Oksana Marukhlenko}

\section{INTRODUCTION}

According to Art. 1 of the Ukrainian Constitution, Ukraine is a social state. Prioritized principles of such a state include the public welfare and development. In general, the level of the population wellbeing is determined by the volume and structure of the consumption, the totality of the current incomes and savings, the provision of the living conditions etc. It serves as one of the important characteristics of theliving conditions for the population and its social protection. The studies show the close link between the social development tothe growth rates and social protection strategies.

According to Art.11 of the Law of Ukraine dated 1 July 2010 No. 2411-VI "On the Foundations of Domestic and Foreign Policy", it is determined that one of the main tasks of the state policy is to ensure the improvement of the people well-beingwith a focus onthe full economic development and integration of the Ukrainian economy into the world economic system. Thus, raising the level of the social development is an urgent task of both economic and social policy of the Ukrainian state. It actualizes the need to understand the issues of the formation, application and evaluation of the investment mechanisms effectiveness inthe public policy by ensuring the social development.

\section{The content of the concept "administration mechanism"}

The basic element of the term "the investment mechanism of the public policy " is the concept of the mechanism itself. Mechanisms are different in design and purpose, forming the basis of most machines, appliances and devices. In economics, the term "mechanism" is used 
figuratively and means "an internal structure, the system of something." Most likely this term is borrowed from the natural and technical sciences. "Mechanism" in Greek is translated as "a weapon, a machine" and nowadaysit has the following essential meanings:

1. The device for transmitting and converting movements in which the movement of one or more elements causes certain movements of the rest.

2. An internal device, an internal structure of the machine, an equipment.

3. The set of states and processes that make up any physical, chemical, physiological, economic, and psychological phenomenon.

4. The system, device, method that determine the order of a particular activity ${ }^{1}$. The mechanism of the public policy is a complex management category.

In general, all available management mechanisms can be divided into three types: the mechanisms as tools, the mechanisms as systems (the set of interconnected elements), and the mechanisms as processes (the sequence of certain transformations).

The mechanism of the public administration is the mechanism as a system intended for the practical implementation of the public administration and the achievement of the set goals, which has the defined structure, methods, levers, instruments of the influence on the object of the management with the appropriate legal, regulatory and information support (Fig. 1).

However, the composition of the public administration mechanism for a particular area of the social development will change, depending on the specific nature of the particular area.

Inpublic administration there are different approaches to the types and classification of the public administration mechanisms. We agree with N. Bryukhovetska's opinion that "the administration mechanism will have its own name according to the focal points in

${ }^{1}$ DiNitto D. M. (2003) Social Welfare: Politics and Public Policy. Boston: Pearson Education. 450 p. 
certain spheres of management"2 . Depending on the problems and the ways they are solved with the use of the specific administration mechanism, it can be complex and include several separate mechanisms.

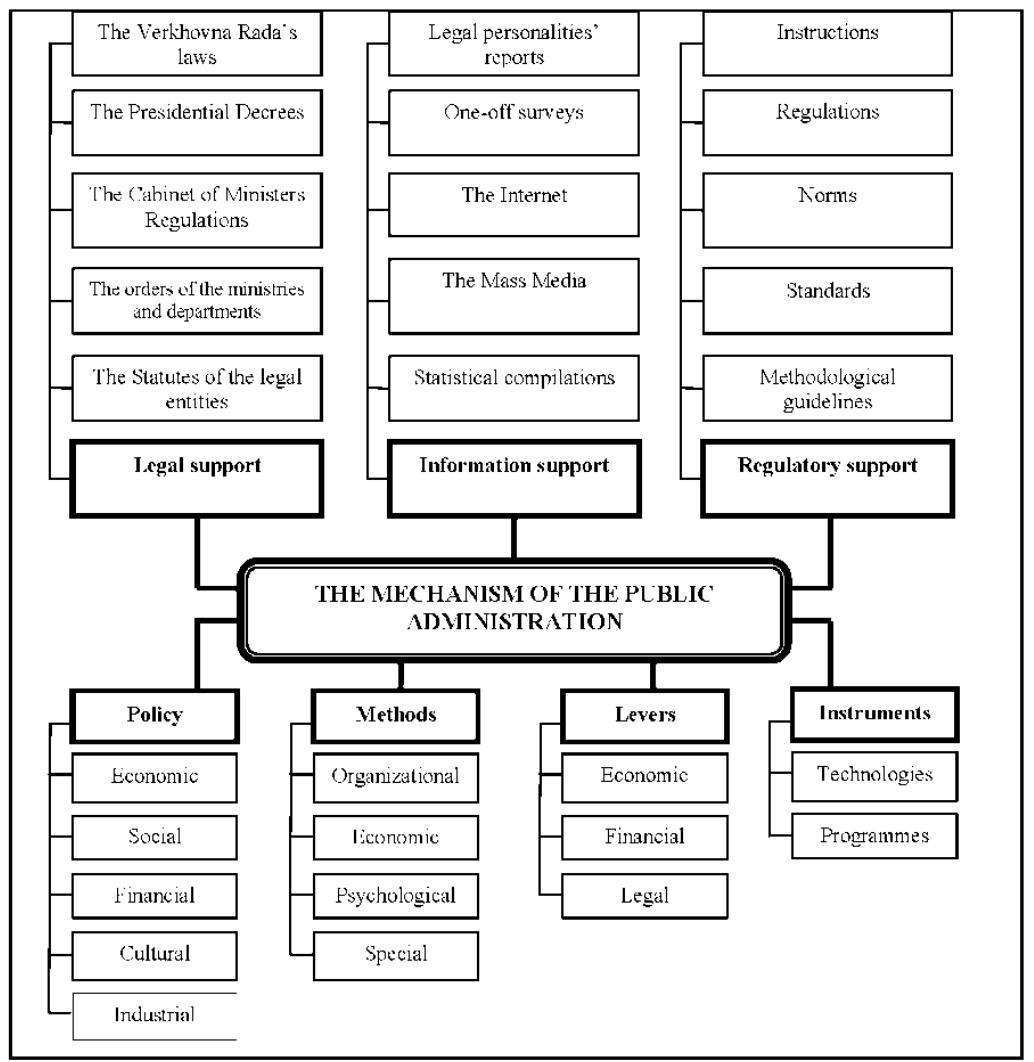

Fig. 1. The structure of the public administration mechanism ${ }^{3}$

${ }^{2}$ Yuzkov L.P (1993) Ghosudarstvennoe upravlenye v polytycheskoj systeme razvytogho socyalyzma [Public administration in the political system of the advanced socialism]. Kyiv. (in Ukrainian)

${ }^{3}$ Yuzkov L.P (1993) Ghosudarstvennoe upravlenye v polytycheskoj systeme razvytogho socyalyzma [Public administration in the political system of the advanced socialism]. Kyiv. (in Ukrainian) 
The complex mechanism of the public administration may consist of the following types of mechanisms:

- economic (the mechanisms of the public administrationin banking, financial activities, investment operations, innovation activities, credit operations, taxation, insurance business etc.);

- motivational (the set of the command-administrative and socio-economic incentives that encourage public officials to work effectively);

- organizational (the objects and subjects of the public administration, their goals, tasks, functions, management methods and organizational structures, as well as the results of their functioning);

- political (the mechanisms of the economic, social, financial, industrial policy formation etc.);

- legal (the legal and regulatory support: the laws and regulations of the Verkhovna Rada of Ukraine (hereinafter VRU), the decrees of the President, the resolutions and orders of the Cabinet of Ministers of Ukraine (hereinafter CMU), as well as the methodological recommendations and instructions etc.).

It should be noted that in addition to the comprehensive mechanism of the public administration, there are also non-state mechanisms of management, namely business, confessional, corruption, party etc.

O. Korotych distinguishes the classification of the public administration mechanisms based on the subjects of management ${ }^{4}$. According to this feature, in Ukraine the mechanisms of the public administration are divided into those implemented by governing bodies:

- at the highest level (VRU, President, CMU);

- at the regional level (the regional councils, the regional state administrations (hereinafter RSA));

4 Bryukhovetska N.Yu. (1999) Ekonomichnyj mekhanizm pidpryjemstva $v$ rynkovij ekonomici: metodologhija $i$ praktyka [The economic mechanism of an enterprise in the market economy: methodology and practice]. Donetsk: IEP NAN of Ukraine. (in Ukrainian) 
- at the district level (the district councils, the district state administrations);

- at the local level (the city, town, village councils).

The generalized classification of the public administration mechanisms is presented in Fig. 2.

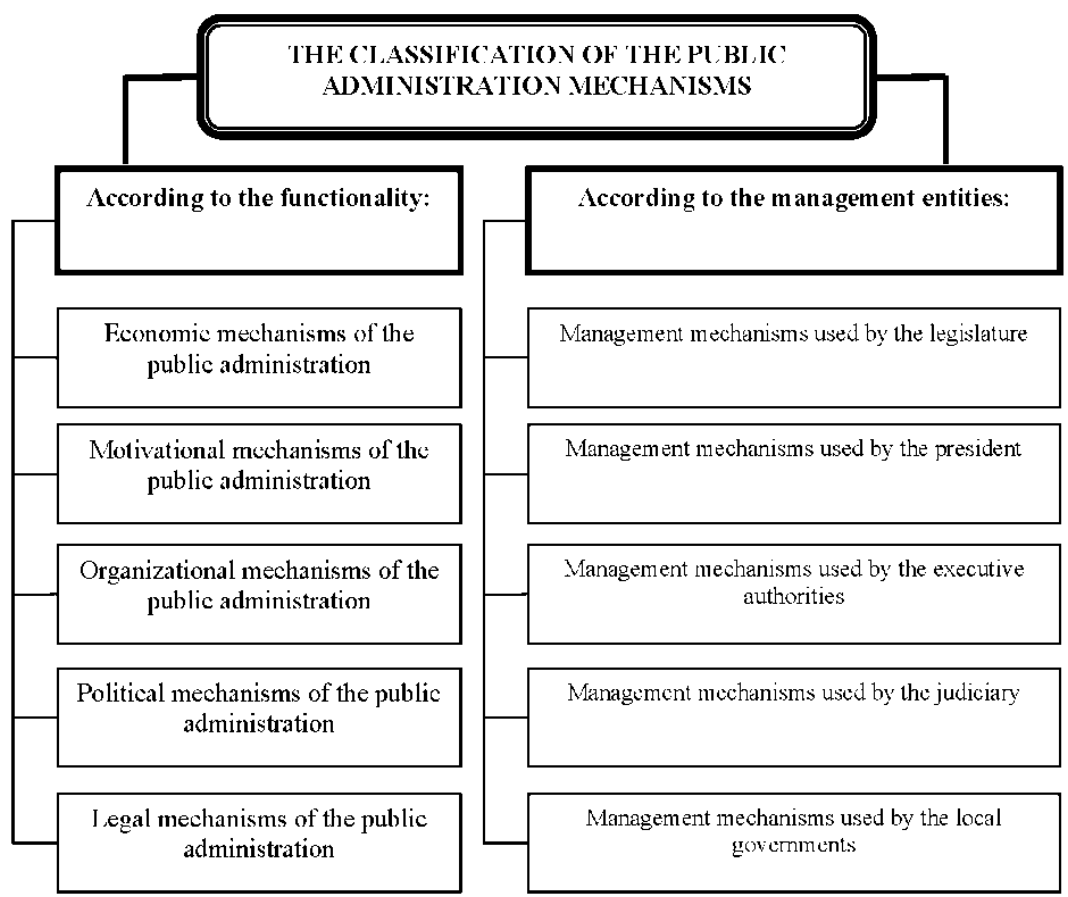

Fig. 2. The classification of the public administration mechanisms

It includes the devision of the public administration mechanisms according to their functions andmanagement entities.

The question of the mechanisms is one of the central issues concerningthe state regulation of any public processes. The scientific literature on public administration offers various approaches to the understanding the nature and functionality of the state and public administration mechanisms. In that regard, the Ukrainian researcher T. Butyrska believes that in public administration not every decision 
can be considered as the mechanism of the management, but only the decision that is subordinated to the logic of the development.The management of this development involves the constant formation of the picture for the future, the formation of the ideas, the implementation of which coincides with the practical solution of the problems ${ }^{5}$.

H. Atamanchuk emphasizes the institutional nature of the public administration mechanisms understanding under them the complex system of the state bodies organized in accordance with certain principles for carrying out the tasks of the public administration. Within this approach, the mechanism of the public administration is perceived as a "tool" for the implementation of the executive power of the state aimed at fulfilling certain functions ${ }^{6}$. Considering the mechanisms of the public administration in the social sphere (on the example of the social protection for disabled people), K. Mishchenko proposes to identify programme-targeted, organizationaladministrative, economic, social-psychological and administrative mechanisms. Their tasks are to perform the regulatory, coordinating, motivational and other functions.

The systematic approach to the understanding of the public administration mechanisms is demonstrated by R. Rudnytska, O. Sydorchuk and O. Stelmakh, who believe that such mechanisms are an "artificially created complex system designed to achieve set goals, which has a defined structure, the set of the legal norms, methods, means, instruments of the state influence on the object" "7. And when it

5 Korotych O.B. (2006) Derzhavne upravlinnja reghionaljnym rozvytkom Ukrajiny [The public administration of the regional development of Ukraine]. Kharkiv. (in Ukrainian)

6 Astapova H.V. Astapova Ey.A., Loiko D.P. (2001) Orghanyzacyonnoekonomycheskyj mekhanyzm korporatyvnogho upravlenyja $v$ sovremennykh uslovyjakh reformyrovanyja ekonomyky Ukrayny [The Organizational and economic mechanism of the corporate governance in the current conditions of reforming the Ukrainian economy]. Donetsk. (in Ukrainian)

Kovaluk O.M. (2002) Finansovyj mekhanizm orghanizaciji ekonomiky Ukrajiny (problemy teoriji i praktyky) [The financial mechanism of the organization of 
comes to the system, it is important to take into account its properties such as the presence of the subsystems that are dynamically interacting, the presence of "logging out" in the form of the made state decisions, the feedback, synergetic effects etc.

The Ukrainian scientist V. Bakumenko emphasizes the process of the management which, by his definition, is the interaction of the subject (the management system) and the object (the system which is governed). The management entity in the communication process acts on the management object through certain managerial influences. They should trigger an action (event) in the management object. Such actions should change the environment in the direction desired for the subject. In this case, the management object manifests itself inthe actions which are the result of the economic, political, and social activities. In this way, the subject and object of the management are in the constant dynamic interaction. However, the managed object is by no means passive; it actively participates in the formation of the nature and direction of the managerial influence, which is covered by such a concept as the "feedback"

Within the structural approach, the management mechanism is considered as the lower level of the system hierarchy in relation to the administration system. This mechanism should consist of the set of certain parts, that is, have an internal structure. The most common requirement for the structural elements of the management mechanism is to determine its structure, that is, the justification of the necessary and sufficient composition of its components. For each of the substantiated and selected components of the management mechanism it is necessary to determine the essence, results and functions.

Summarizing the functional, structural approaches and the understanding of the public administrationmechanisms I. Cherlenyak

the Ukrainian Economy (The problems of the theory and practice)]. Lviv. (in Ukrainian)

8 Yeremenko-Hryhorenko O.A. (1999) Orghanyzacyonno-ekonomycheskyj mekhanyzm upravlenyja khozjajstvennoj dejateljnostjju predpryjatyja [The organizational and economic mechanism of the management inthe economic activity of the enterprise]. Donetsk. (in Ukrainian) 
emphasizes that the management mechanism must unite the management entity, the management object, management goals and conditions based on the certain autonomous principle of coordination and organization. The author divides the mechanisms into two large groups:

- general mechanisms are the set of autonomously coordinated links between the structure, functions for the structures of the state power and the structure, the functions of the society structures and the structures of the economy to ensure the process of the socio-economic reproduction and the comprehensive development of the state. Autonomous coordination is ensured by the system of the constitutional and administrative law, the autonomy of the economic system, the traditions of the human and citizen rights protection;

- special mechanisms are the groups of coordinated relations between the functions of the special state body or institution and the functions for the structures of the economy and society, that is, the interaction coordinated by the legal system and conditions of the socio-political and socio-economic development, between the decision-making process and the processes of their implementation and evaluation; the financial, economic, investment, legal, motivational mechanisms of the public administration ${ }^{9}$.

Thus, when considering the mechanisms of the public administration for the social development, we should first of all pay attention to the general guidelines of the management system, that reflect its most significant characteristics, which follow from the theory and methodology of the public administration. The complexity of the forming, applying and evaluating the public management mechanisms in the social development lies in the ambiguity of the understanding the essence of the concept "social development". Within the conventional view of the social development as the well-

9 Amosov A.Yu. (2001) Peretvorennja mekhanizmiv derzhavnogho reghuljuvannja ekonomichnogho rozvytku [The transformation of the mechanisms of the state regulation for the economic development]. The public administration and local self-government, vol. 2, pp. 10-16. 
being of the population and its interpretation through the categories of needs and benefits, the indicators of the social development are:

- per capita income level, the provision of the material and technical resources to households;

- the level of the population differentiation according to their income and consumption;

- the cost of living;

- the absolute and relative poverty;

- the standard of living (the standard of consumption).

Thus, the social development is directly related to the concept of the population well-being and it determines the absolute and relative level of providing the needs of the person (family) by tangible and intangiblebenefits, in particular spiritual, in comparison with the standards and norms adopted in a particular society or social group, as well as compared to the international standards.

The international regulatory legal acts, to which Ukraine acceded and ratified in due course, and which, in their turn, according to the international law have a higher legal force in comparison with the Ukrainian legislation, play an important role in establishing the management goals for public welfare. According to Art. 25 of the Universal Declaration of Human Rights (1948), it is stated that everyone has the right to the standard of living (including food, clothing, housing, medical care and necessary social services) that is necessary to maintain the health and well-being of any person and a family. The European Social Charter (1961) proclaimed the human right to social progress.

At the same time, in the post-industrial society, which is characterized by the transition to the knowledge economy, a special emphasis is placed on human capabilities, the development of the creative and intellectual potential. Therefore, the human dimension that includes education, science, culture, information technology, spirituality, which determine the quality of life,becomes the core of the modern social system.According to the American philosopher D. Bell, "an industrial society is determined by the quantity of goods, which testifies to the standard of living, whereas a post-industrial society is 
determined by the quality of life, measured by services and amenities, namely health care, education, recreation, arts development ... "10. This is about the social development, which components, according to I. Horhes, O. Petroye, V. Skurativsky, P. Sytnyk, V. Troschinsky ${ }^{11}$ are as follows:

- the development of the humanitarian sphere (health care, education, science), as well as the humanitarian policy for the development of cultural institutions and infrastructure;

- the implementation of the state policy in the sphere of the religious life;

- the development of the social sphere (social relations, payment and safety for labour, social partnership and social dialogue);

- providing social security (social protection, social insurance, social assistance, social work).

It is social development that forms the basis for achieving the well-being of the population.

With regard to the transformation of the views on the population well-being, the question arises as to the goals and objectives of the public welfare policy and the general guidelines of the managed system. According to the American researcher D. DiNitto, the public welfare policies include a number of policy issues (measures) for the poor, those who are atrisk to become poor and the rich. The boundaries of such a policy are vague. It is therefore viewed in a broad and narrow sense. In broad terms, such policies cover almost all the public policy measures, from taxation, national defense and energy conservation to health care, housing and social assistance programmes. In a narrow sense, it is a state policy that directly affects citizens' incomes, services and opportunities for the socially vulnerable groups

${ }^{10}$ Obolensky O. (1998) Derzhavna sluzhba Ukrajiny: realizacija systemnykh poghljadiv shhodo orghanizaciji ta funkcionuvannja [State Service of Ukraine: Implementation of Systematic Views on Organization and Functioning]. Khmelnytsky: Podillya. (in Ukrainian)

11 Artemenko V. (2003) Osnovy vymirjuvannja reghionaljnogho rozvytku z vykorystannjam koncepciji jakosti zhyttja [Fundamentals of measuring the regional development using the concept of quality of life]. Region, economy, vol. 2. pp. 134. 
of the population (the elderly, the poor, the disabled and the sick etc.) $)^{12}$.

The welfare policy should be based on an assessment of the current problems of the socio-economic status of the Ukrainian population. The data of the State Committee of Statistics in Ukraine and Social Surveys give grounds to highlight the following trends in recent years:

- the propertyaspect, the socio-economic stratification of the population, the reduction of the share forthe labor income in the welfare structure;

- the low level of the purchasing power of the population, the presence of the layer of the people earning income on the margin of poverty, including some employees of the budget sector;

- the high level of the "psychological poverty" when 70-80\% of people consider themselves poor;

- the existence of the "grey market" and the illegal or semiillegal employment without social guarantees, difficulties in the employment and realization of the potential, including intellectual, especially for young people;

- the labour migration, the outflow of the labour, mainly of the reproductive age;

- the low employment rate of disabled people, most of whom are of working age;

- the coverage of various social benefits and social assistance up to $70 \%$ of the population, the inclination of the part of the population to the social maintenance and at the same time the insufficient development of the network of the modern social institutions intended for the representatives of socially vulnerable population groups;

12 Fertikova T.M. (2007) Dobrobut jak ob’jekt derzhavnoji socialjnoekonomichnoji polityky $\mathrm{v}$ Ukrajini [Well-being as an object of the state socioeconomic policy in Ukraine]. Nauk. pr. Chornomor. derzh. un-tu im. P. Moghyly. Ser. «Ekonomika» [Science. Petro Mohyla Black Sea National University. "Economy"] (electronic journal), vol. 51, no. 64. Retrieved from: www.nbuv.gov.ua/ Portal/Soc_Gum/Npchdu/Economy/2007_51/5 1-4.pdf. (accessed 10 January 2019). 
- the "greying" of the nation which causes the significant economic and demographic burden on the able-bodied citizens;

- the spread of the socially dangerous diseases (tuberculosis, HIV/ AIDS, and other sexually transmitted diseases, drug addiction etc.), which is an indicator of a nation's social "ill health";

- the lack of the resources, both public and private, to improve and maintain a healthy lifestyle;

- the commercialization of the health care system, the unavailability of the medical services and medicines due to their high cost to a large proportion of the population;

- the decrease in the quality of the secondary, special and higher education, inaccessibility of quality higher educationfor many families;

- the limited ability of the large part of the population to satisfy cultural needs.

Taking into account the current ideas about the directions of the population welfare growth and the current situation in Ukraine gives grounds to determine the tasks of the public administration in the field of the social development. The management objects should be:

1) the level of incomes (the expenditures and savings of the population), in particular, the level of the employment, wages, property income, social transfers and the provision of social services;

2) the availability of the benefits important for the preservation and accumulation of the human capital, namely:

- health and education which affects employment and income;

- public goods;

- the benefits that are not vital, but the opportunity to receive them is an incentive for the active economic behaviour.

This means that the essence of the state influence in the transition economy and the formation of the social state should stimulate market mechanisms and implement the principles of a socially oriented market economy as well, and to implement the effective social policy.

The public administration of the social development is the mechanism for achieving the goals of the economic and social policy 
based on the legislative imperatives that determine the real standard of living, well-being, employment, social support. At the same time, by the definition of V. Skurativsky and A. Skurativsky, the social policy must be based on the three basic principles:

1) the priority of the problems in the social protection of the population;

2) increasing the role of the personal labour income in meeting the socio-cultural and household needs of the population and eliminating dependency on this basis;

3 ) the organization of a new mechanism for financing the social sphere, that is the transition from the state paternalism to the social partnership.

The social protection of the population in the conditions of the transition to the market requires the differentiation of the social support according to the level of incomes, the degree of the working capacity, and in some cases based on the principle of the employment in the social production. Some sections of the population need special social programmes, which is caused by the presence of a high degree of the social inequality in the Ukrainian society. The implementation of such management approaches will help to achieve approximation to the European quantitative standards of the social development, which, in particular, is provided by the Law of Ukraine (as amended) "On the State Social Standards and State Social Guarantees" dated 5 October 2000.

The conditions of the public administration inthe social security of the population are determined by the specific social welfare of the population as a management object. First of all, we are talking about multi-entity, multi-level, weak structured social sphere, which has the capacity for the self-organization. Moreover, it should be borne in mind that the social reproduction is a complex, multiple, ambiguous process that is influenced by the global trends and international commitments of the country, the state of the legal culture and social values.

The social sphere and social relations are closely linked to economic issues. After all, the economic decisions of the state related 
to, for example, the macroeconomic stability and the reduction of the budget expenditures, which are simulteniously social in their consequences, since their implementation will affect the income of the population and the level of its social protection. At the same time, it is important to note that the initial socio-economic status is not considered by many scholars to be the determining factor for the development of the social well-being. It is true that the economies of Germany and Japan were completely destroyed at the end of World War II, but the rapid socio-economic growth soon began. At the time of the collapse of the Soviet Union, Ukraine and other post-Soviet countries had a full-fledged economy and the ample opportunities for the development but for almost 20 years of the independence there had been a social and economic setback. This leads to the conclusion that for the social development of the state is not so much economic power as the organizational principles of the embodied form of the state (including those embodied in the relationship "power - society") 13 . That is, the degree of the authorities responsibility to the society also determines the state of the population well-being as a management object.

In modern Ukraine, financing of the socio-economic programmes is carried out not only at the expense of the state funds, but also at the expense of the local budgets, the funds of the enterprises, organizations, and the population. Charitable social assistance funds can play a certain role in improving the well-being of the population. Therefore, a purposeful mechanism for managing the public welfare is implemented through specific public institutions, namely the entities that collectively form the governing system, which includes the state (in particular, the President of Ukraine, the Verkhovna Rada of Ukraine, the Cabinet of Ministers of Ukraine, the

13 Kovalska N. (2014) Teoretyko-metodologhichni zasady mekhanizmiv derzhavnogho upravlinnja systemoju profesijnoji pidghotovky v Ukrajini [Theoretical and methodological foundations of the mechanisms of the state management for the training system in Ukraine]. Aktualjni problemy derzhavnogho upravlinnja [Actual problems of public administration] (electronic journal), no. 2 (54), pp. 8. Retrieved from: http://nbuv.gov.ua/UJRN/apdyo_2013_2_4. (accessed 10 January 2019). 
relevant central bodies of the state power), political parties, nongovernmental organizations and others.

At the regional and local levels of management, these functions are performed by the relevant authorities and institutions. The highest level of the competence, professionalism of the civil servants and employees of the relevant institutions, the respectful attitude to solving problems for the people becomes the main indicator of the public welfare in the daily life of the population, the indicator of the effectiveness of the economic and social policy of the state at the regional and local levels. At the present stage, there is a duplication of the functions for the authorities in ensuring the welfare of the population, the lack of the coordination and interaction in the management structures at different levels. Another problem is that in Ukraine the functions of the regional local authorities are wider than in many other countries of the world, with the minimal financial resources for their realization. The way out of this situation should be the social obligations of the state, which can be defined as a legally fixed set of social benefits, i.e. services, benefits, subsidies etc. The state is obliged to make them available to those citizens who need them at the expense of the budgetary resources.

The identified problems raise the issue of the specialization for the levels of public administration to ensure the welfare of the population. In the presence of the general objectives of the social development, such specialization can ensure the formation of the integrated system of the socio-economic policy, which is based on all branches of the state power, local self-government and especially the activity of citizens. Within the integrated system of the responsibility for the realization of the social goals and objectives, it is necessary to distinguish the following key levels: central, regional, local selfgovernment bodies, production structures, citizens. At the central level, the following issues need to be addressed:

- the development of the legal framework regulating the division of the competences in the sphere of ensuring the well-being of the population between the central, regional and local self-government bodies; 
- the development of the clear mechanisms for the implementation of the laws, the priority financial support of the state social programmes;

- the regulation of the minimum wage and pension;

- streamlining benefits and social guarantees;

- the creation of the favourable tax conditions for the development of the charitable assistance, the regulation of citizens' access to medical, educational, social, socio-cultural services, the regulation of the issues related to the labour migration and the development of the social and labour relations;

- the creation of the effective system of the civil rights protection and security.

At the regional level, the main promising areas for improving the social welfare of the population should be:

- the elaboration and implementation of the programmes for the economic development of the region;

- the effective measures in the labour market to optimize the employment structure and reduce the unemployment;

- the elaboration and implementation of the priority programmesrelating to the social support for the families, children, women, people with disabilities, other vulnerable groups of the population;

- the creation of the single regional information space, monitoring of the indicators for the social sphere of the region;

- the separation of the powers to ensure the social welfare for the population at the regional level and at the level of local selfgovernment bodies;

- ensuring the stable funding for the targeted social assistance;

- providing the continuous improvement of the quality for the social, medical, educational and other services (in the context of the modern technologies of the XXI century).

The public administration of the social development must be based on both general and specific governance mechanisms. The task of the social development management is to specify the general objectives of the higher state level, taking into account the formed 
system of the public administration, local self-government, as well as the socio-economic conditions and constraints existing in the state and relevant to the social sphere. The management objects should include both the level of incomes and the availability of the benefits essential for the preservation and accumulation of the human capital, comprising the educational, medical and social services.

Today the investment mechanism of the Ukrainian social development is an open system with the vague boundaries, which is caused by the multi-entity, multi-level, the weak structured social sphere and ambiguous understanding of the social development as an object of governance. Increasing the development of the social potential is possible only under the condition of the differentiation of the management activity in accordance with the objects of the influence and the problems, without which it is impossible to define the boundaries for the management.

Thus, let us consider in more detail the organizational structure of the investment mechanism of the public policy in the public development. In theresearches, the description of the organizational structure forthe public policy mechanism often begins with the identification of its elements. O. Fedorchak points out the following main elements: methods, levers, tools, policy, legal, regulatory and information support. At the same time she notes that the composition of the public administration mechanism in the certain sphere of the social development will change, depending on the features of the particular sphere ${ }^{14}$.

In the mechanisms of the public policy L. Prykhodchenko identifies the target, regulatory, organizational, economic and information components. She claims that the target component is a primary element of the mechanism's structure. The legal part of the

14 Fedorchak O.V. (2008) Klasyfikacija mekhanizmiv derzhavnogho upravlinnja [Classification of the mechanisms of the public administration]. Demokratychne vrjaduvannja [Democratic governance] (electronic journal), vol. 1, Retrieved from: http://www.nbuv.gov.ua/e-joumals/DeVr/2008-01/O_Fedorchak.pdf. (accessed 10 January 2019). 
second component defines all the possible sets of the modes for functioning, whereas the normative part of the second component is formed through the orders and decisions of the local authorities. In this case, the change of the legal acts is much slower than that of the normative ones, which makes the latter more important for the functioning of the public administration mechanism. The functionality of the organizational component involves defining the rights, responsibilities, competencies, and responsibilities inthe decisionmaking process. The relationship between the organizational and regulatory components shows that the legal documents regarding the allocation of the competences set boundaries but do not define the internal content. The latter happens in the process of functioning of the organizational component. The essence of the economic component is to evaluate the results of the management process. Accordingly its purpose is to assess the effectiveness of the management decisions. An indispensable component of any mechanism of the public administration is the informational part, which actually has a crosscutting effect. The content characteristic of this component contains the structure of the information database, the sources and consumers of the information, the technological process of its processing ${ }^{15}$.

V. Bodelan views the organizational structure of the public administration mechanism as a set of management units and organizational links between them for the realization of the goals and objectives of the state as a whole or in a separate direction. In his opinion, it characterizes the relationships of the set of the units and the existing organizational links between them, which express the interaction and coordination of the elements within the system. Its interaction and coordination are based on the goals and objectives that are realized through the functions. Moreover, the functions are

${ }^{15}$ L. Prykhodchenko (2009) Struktura mekhanizmu derzhavnogho upravlinnja: vzajemozv'jazok komponentiv ta faktory vplyvu na efektyvnistj [The structure of the mechanism of the administration: the interconnection of the components and factors of the influence on efficiency]. Bulletin of the National Academy of Public Administration under the President of Ukraine, vol. 2, pp. 108-110. 
essential for the organizational structure, they determine the need for the certain elements of the system and the architecture of this system. Therefore, the organic interconnection of the organizational structure and the functional structure in practice leads to the fact that they appear as a whole, as an organizational and functional structure, built on the principle of the division of the functions vertically and horizontally for the structure. He points out that the practice convincingly shows that the formation of the organizational and functional structure should be carried out according to H. Chandler's well-known principle "a strategy defines a structure" in this way:

- establishing of the goals and sub-goals;

- defining of the functions and sub-functions necessary for the realization of the goals and sub-goals;

- creating of the appropriate structures (entities) to perform the certain functions ${ }^{16}$.

Yu. Kunayev, studying the issues for the management in the customs service, considers the structure of the public administration mechanism as a set of 6 components:

- the target part as a set of all the goals for the management activities;

- the functional part that includes the types of the management activities (cognitive-programmatic and organizationally regulatory) necessary to perform the basic functions of the organization;

- the methodological part involves those methods that are used in the performance of all the types of the management activities, i.e. they ensure the implementation of the functional part;

- the part that reflects the set of the principles, norms or rules according to which it is necessary to perform successful management activities;

16 Bodelan V.R. (2013) Orghanizacijno-funkcionaljni struktury: osoblyvosti vplyvu chynnykiv jikh pobudovy na efektyvnistj funkcionuvannja orghanizacijnogho mekhanizmu derzhavnogho upravlinnja [Organizational and functional structures: features of the influence of the factors relating to their construction on the efficiency of functioning of the organizational mechanism of the public administration]. Public administration: theory and practice, vol. 3. pp. 55. 
- the instrumental part comprises the management decisions, powers, means of the information, material and energy influence on the management object;

- the technological part implies the technology of the preparation, adoption and execution of the management decisions.

Considering the above views of the various researchers on the structure of the public administrationmechanism, we can draw the following conclusions:

- the main emphasis is made on the constituents of the mechanism, and their description has a rather general direction;

- less attention is paid to the interconnections between the components of the mechanism;

- the goals and the subjects of the mechanism are not always distinguished as separate constituents;

- there is no clear relationship between the definition of the public administration mechanism and its structure;

- the functions determine the organizational structure of the public administration mechanism and cause the necessity for certain entities;

- the organic interconnection of the organizational and functional structure of the mechanism in practice leads to the understanding as a whole, as its organizational and functional structure.

However, the current state of the domestic economy requires the implementation of the structural transformations of the investment mechanism concerning the public policy in the social development aimed at forming a competitive environment founded on the innovative basis of such mechanism. In the current context, the elaboration and implementation of the mechanisms for the active public policy in the investment sphere, as well as a flexible system of the interaction between the market structures and state regulation, become particularly relevant. 


\section{The investment mechanism of the public policy in the social development}

The practical achievement of the objectives for the investment policy is connected with the creation and ensuring the effective functioning of the mechanism for its implementation. However, it should be noted that the authors of a number of scientific works, when considering the issues onthe investment management, usually focus on the methods with the help of which it is possible to influence this type of the activity, avoiding the content and structure of such a category as the "mechanism of the investment policy implementation".

The distinguished characteristics inherent in this category of "mechanism", combined with the attractiveness of a particular region, allow to open and supplement the meaning of this concept in relation to the investment process. We emphasize that the mechanism (including the investment mechanism) is the result of the purposeful activity and represents a set of the institutions, norms, rules that provide under certain conditions the formation of the given phenomena.

According to the adopted general scheme for building a regulatory mechanism, the model representation of the mechanism under study includes the following elements:

- the subject is the driving force that meaningfullystarts this mechanism;

- the objects include the economic entities, the economic environment;

- the purpose presupposes programmable desired results of the mechanism action;

- the methods involve the tools, modes and technologies of the processes forthe achievement of the set goals;

- the form reflects the organizational and legal registration of the methodological support;

- the means comprise a set of the types and sources of the resources used to achieve the set goals.

There are different points of view regarding the structure of the mechanism for the regional policy implementation, however, there are 
no fundamental differences between them. Thus, the investment mechanism of the public policy in the social development involves public institutions that implement specific measures within the set goal, as well as the resources allocated to achieve the goals and methodological approaches to the formation and implementation of the investment policies that ensure the conduct of the independent policy at the state and regional level.

The investment policy is a system of measures taken by the authorities and management to attract and use the investment resources of all the forms of ownership for the purpose of sustainable and socially oriented development.

The investment policy formation and implementation system should be constructed from three interconnected and interdependent blocks.

The first block incorporates the main factors whichsignificantlyaffect the content of the investment policy and, accordingly, the mechanism of its implementation. They are as follows:

1) the investment climate;

2) the indicators of the investment potentialformation;

3) the level of the investment risks;

4) the factors regarding the internal and external influence.

The first block is mainly related to the objectively determined regional peculiarities of the economy, which in turn determines the complex of the natural geographical, historical, demographic and other factors. The factors of the external influence are connectedwith the influence of the conditions of the activity defined by the national legislation and the national economic and investment policy.

The second block presents the stages of the investment policy formation:

1) defining the goals and main priorities of the investment policy;

2) the formation of the investment programme;

3) the elaboration of the principles for the mechanism of the investment policyimplementation. 
The goals and priorities of the investment policy depend on the goals and objectives of the general socio-economic policy.

The third block of the investment policy implementation mechanism should consist of the means used to achieve the objectives of the policy. The basic tasks of this block comprisethe complex of the applied management methods (economic, administrative, social and psychological) and the system of ensuring its operation (legal, organizational and informational).

The implementation of the investment policy mechanism should become more targeted in terms of the impact of the management structures on all the participants of the investment process in the interests of achieving the set goals of the socio-economic development in the conditions of the insufficient resources.

The formation and implementation of the investment policy is a complex multi-stage system of tasks, where at each stage there are separate elaborations and constant adaptation to the conditions of functioning of the socio-economic system.

The investment mechanism of the public policy for social development should be understood as a system of legal, organizational and economic measures that contribute to the formation of the competitive production and increase of its efficiency. The dynamism of the investment process leads to the presence of the flexible forms of its organization and management, which, in turn, requires the complex regulation of its main stages with a focus on the final results. In the course of the investment activity, all its participants use a combination of different methods with the appropriate variety of forms, incentives and restrictions. All this, of course, reflects the complexity of both the investment process and the mechanism of the public policy implementation for the social development, the essence of which is the purposeful influence of the authorities and management on the development of the investment process in the direction set by the strategic documents of the socio-economic development. Based on this understanding of the essence of the mechanism under consideration, it can thus be emphasized that the investment policy 
is the part of the regional socio-economic policy, so that its implementation should be aimed at achieving the goals of the socio-economic development.

Under the investment mechanism for the public policy implementation in the social development it is necessary to understand the set of methods that ensure the operation of the systems by which the public authorities influence the participants of the investment process in order to solve the primary tasks of the socio-economic development.

The main goals of the mechanism functioning are:

- the mobilization of the investment resources;

- the formation of the investment flows and directing them to the sectors and branches of the economy, where the highest efficiency from investments is provided;

- increasing the efficiency of the investment use;

- the increase of the investment activity.

The content of the investment mechanism of the public policy for the social development can be characterized as a process of the concentration and mobilization of the investment resources, the organization of the control over their effective use, the development of the regulatory influences aimed at strengthening the positive tendencies of the economy as a whole.

This understanding of the content of the proposed mechanism makes it possible to distinguish its main structural components in the form of the separate blocks, each of which has its own content and meaning, which is realized in different forms and by different methods.

The functions that the mechanism is intended to perform are:

- streamlining the reproduction process through the creation of the favourable investment environment and the appropriate system of the state regulation;

- the realization of the investment potential for the territory;

- the formation of the motivational mechanism of the investment process; 
- the reduction of the possible or expected contradictions of the economic interests relating to the investment entities.

\section{CONCLUSIONS}

Thus, the peculiarity of the investment mechanism of the public policy implementation in the current conditions of the destabilization of the economic relations is its focus on reconciling the interests of all the components of the mechanism. That is whythe important part in the structure of the mechanism under consideration is the motivational block, which ensures the interaction of the participants in the investment process not only among them but also with the external environment.

\section{SUMMARY}

The article summarizes the approaches to understanding the mechanisms of the public administration, deals with the content and structure of the investment mechanism of the public policy for thesocial development in view of the modern interpretations relating to the social development, the responsibility of the different levels of the public administration for enhancing the development of the social potential. The issue of the mechanisms is one of the central problems related to the state regulation of any public process.

\section{REFERENCES}

1. DiNitto D. M. (2003) Social Welfare: Politics and Public Policy. Boston: Pearson Education. 450 p.

2. Yuzkov L.P (1993) Ghosudarstvennoe upravlenye $v$ polytycheskoj systeme razvytogho socyalyzma [Public administration in the political system of the advanced socialism]. Kyiv. (in Ukrainian)

3. Bryukhovetska N.Yu. (1999) Ekonomichnyj mekhanizm pidpryjemstva $v$ rynkovij ekonomici: metodologhija i praktyka [The economic mechanism of an enterprise in the market economy: methodology and practice]. Donetsk: IEP NAN of Ukraine. (in Ukrainian) 
4. Korotych O.B. (2006) Derzhavne upravlinnja reghionaljnym rozvytkom Ukrajiny [The public administration of the regional development of Ukraine]. Kharkiv. (in Ukrainian)

5. Astapova H.V. Astapova Ey.A., Loiko D.P. (2001) Orghanyzacyonno-ekonomycheskyj mekhanyzm korporatyvnogho upravlenyja $v$ sovremennykh uslovyjakh reformyrovanyja ekonomyky Ukrayny [The Organizational and economic mechanism of the corporate governance in the current conditions of reforming the Ukrainian economy]. Donetsk. (in Ukrainian)

6. Kovaluk O.M. (2002) Finansovyj mekhanizm orghanizaciji ekonomiky Ukrajiny (problemy teoriji $i$ praktyky) [The financial mechanism of the organization of the Ukrainian Economy (The problems of the theory and practice)]. Lviv. (in Ukrainian)

7. Yeremenko-Hryhorenko O.A. (1999) Orghanyzacyonnoekonomycheskyj mekhanyzm upravlenyja khozjajstvennoj dejateljnostjju predpryjatyja [The organizational and economic mechanism of the management inthe economic activity of the enterprise]. Donetsk. (in Ukrainian)

8. Amosov A.Yu. (2001) Peretvorennja mekhanizmiv derzhavnogho reghuljuvannja ekonomichnogho rozvytku [The transformation of the mechanisms of the state regulation for the economic development]. The public administration and local selfgovernment, vol. 2, pp. 10-16.

9. Obolensky O. (1998) Derzhavna sluzhba Ukrajiny: realizacija systemnykh poghljadiv shhodo orghanizaciji ta funkcionuvannja [State Service of Ukraine: Implementation of Systematic Views on Organization and Functioning]. Khmelnytsky: Podillya. (in Ukrainian)

10. Artemenko V. (2003) Osnovy vymirjuvannja reghionaljnogho rozvytku z vykorystannjam koncepciji jakosti zhyttja [Fundamentals of measuring the regional development using the concept of quality of life]. Region, economy, vol. 2. pp. 134.

11. Fertikova T.M. (2007) Dobrobut jak ob'jekt derzhavnoji socialjno-ekonomichnoji polityky v Ukrajini [Well-being as an object of the state socio-economic policy in Ukraine]. Nauk. pr. Chornomor. 
derzh. un-tu im. P. Moghyly. Ser. "Ekonomika" [Science. Petro Mohyla Black Sea National University. "Economy"] (electronic journal), vol. 51, no. 64. Retrieved from: www.nbuv.gov.ua/ Portal/Soc_Gum/Npchdu/Economy/2007_51/5 1-4.pdf. (accessed 10 January 2019).

12. Kovalska N. (2014) Teoretyko-metodologhichni zasady mekhanizmiv derzhavnogho upravlinnja systemoju profesijnoji pidghotovky v Ukrajini [Theoretical and methodological foundations of the mechanisms of the state management for the training system in Ukraine]. Aktualjni problemy derzhavnogho upravlinnja [Actual problems of public administration] (electronic journal), no. 2 (54), pp. 8. Retrieved from: http://nbuv.gov.ua/UJRN/apdyo_2013_2_4. (accessed 10 January 2019).

13. Fedorchak O.V. (2008) Klasyfikacija mekhanizmiv derzhavnogho upravlinnja [Classification of the mechanisms of the public administration]. Demokratychne vrjaduvannja [Democratic governance] (electronic journal), vol. 1, Retrieved from: http://www.nbuv.gov.ua/e-joumals/DeVr/2008-01/O_Fedorchak.pdf. (accessed 10 January 2019).

14. Prykhodchenko L. (2009) Struktura mekhanizmu derzhavnogho upravlinnja: vzajemozv'jazok komponentiv ta faktory vplyvu na efektyvnistj [The structure of the mechanism of the administration: the interconnection of the components and factors of the influence on efficiency]. Bulletin of the National Academy of Public Administration under the President of Ukraine, vol. 2, pp. 108-110.

15. Myrna N.V. (2010) Opracjuvannja kompleksnogho mekhanizmu derzhavnoji reghionaljnoji polityky [Elaboration of a complex mechanism of the state regional policy]. Derzhavne budivnyctvo [State building] (electronic journal), v0l. 1. Retrieved from: http://nbuv.gov.ua/j-pdf/DeBu_2010_1_20.pdf. （accessed 10 January 2019).

16. Bodelan V.R. (2013) Orghanizacijno-funkcionaljni struktury: osoblyvosti vplyvu chynnykiv jikh pobudovy na efektyvnistj funkcionuvannja orghanizacijnogho mekhanizmu derzhavnogho 
upravlinnja [Organizational and functional structures: features of the influence of the factors relating to their construction on the efficiency of functioning of the organizational mechanism of the public administration]. Public administration: theory and practice, vol. 3. pp. 55.

Information about the author: Oksana Marukhlenko, $\mathrm{PhD}$ in Economics, Doctoral Student at the Department of Social and Humanitarian Policy, National Academy of Public Administration under the President of Ukraine 20, Ezhena Potie str., Kyiv, 02000, Ukraine ORCID ID: orcid.org/0000-0001-8050-6615 